\title{
Clinical utility of a life quality score in dogs with canine transmissible venereal tumor treated by vincristine chemotherapy
}

\author{
[Utilidade clínica de escala de qualidade de vida durante o tratamento quimioterápico de cães \\ com tumor venéreo transmissível canino (TVTC) com vincristina] \\ M.L. Valladão ${ }^{1,2}$, K.C. Scarpelli ${ }^{2}$, K. Metze $e^{3 *}$ \\ ${ }^{1}$ Aluna de pós-graduação em Fisiopatologia - FCM-UNICAMP - Campinas, SP \\ ${ }^{2}$ Centro de Controle de Zoonoses - Taubaté, SP \\ ${ }^{3}$ Faculdade de Ciências Médicas - UNICAMP - Campinas, SP
}

\begin{abstract}
The clinical utility of a life quality score during vincristine chemotherapy of dogs with canine transmissible venereal tumor (CTVT) was investigated using 93 tumor-bearing dogs in this prospective study. At diagnosis, clinical data and the performance status were evaluated according to a modified Karnofsky score (CKS) adapted for dogs. The animals were treated with vincristine sulphate $(0.025 \mathrm{mg} / \mathrm{kg})$ at weekly intervals until the tumor had macroscopically disappeared. The time until the first adverse event and death were recorded. In a pilot study, CKS revealed a high inter-observer concordance (kappa=0.735; weighted kappa=0.835). CKS permitted a detailed monitoring of adverse effects during therapy. Cox regressions showed that low performance score and reduced body weight were independent predictive factors for death during chemotherapy. The modified Karnofsky performance score is a simple and reproducible clinical instrument, able to estimate patient outcome after treatment of CTVT.
\end{abstract}

Keywords: canine transmissible venereal tumor, vincristine, survival, performance score, quality of life

\section{RESUMO}

Investigou-se a utilidade clínica de uma escala de qualidade de vida durante o tratamento quimioterápico de cães com tumor venéreo transmissível canino (TVTC) em 93 animais com TVTC que compuseram este estudo prospectivo. Ao diagnóstico, foram avaliados os dados clínicos e o escore de qualidade de vida adaptado para cães (CKS). Os animais foram tratados com sulfato de vincristina $(0.025 \mathrm{mg} / \mathrm{kg})$ semanalmente até o desaparecimento macroscópico do tumor. Foram anotados o tempo até o aparecimento do primeiro evento adverso e a morte. Em estudo piloto do CKS, alta concordância entre os observadores foi demonstrada (kappa $=0.735$; weighted kappa $=0.835$ ). O CKS permitiu um detalhado monitoramento dos eventos adversos durante a terapia. A regressão Cox multivariada demonstrou que o baixo escore de qualidade de vida e o reduzido peso corporal foram fatores preditivos independentes para o óbito durante a quimioterapia. A escala modificada de Karnofsky é um instrumento clínico simples e reproduzível, hábil em estimar os efeitos do tratamento no TVTC.

Palavras-chave: tumor venéreo transmissivel canino, vincristina, sobrevida, escala de qualidade de vida

\section{INTRODUCTION}

The canine transmissible venereal tumor (CTVT), which affects predominantly external genitalia, is easily transmitted through injured skin and mucosa by transplantation during sexual intercourse. There is strong evidence that the tumor was originated from a wolf or an East
Asian breed of dog between 200 and 2,500 years ago and from than on had been transmitted from animal to animal like a parasite (Murgia et al., 2006). The tumor is commonly diagnosed in free roaming dogs and is frequently found in rural areas of the State of São Paulo, which has a high density of the canine population estimated in about one dog per four inhabitants (Alves et al.,

Recebido em 24 de junho de 2009

Aceito em 10 de setembro de 2010

*Autor para correspondência (corresponding author)

E-mail: kmetze@fcm.unicamp.br 
2005). Tumor-bearing dogs are often brought by the local inhabitants to the Centers of Zoonosis Control. Although there are several types of treatment, such as surgical excision, radiotherapy, or immunotherapy, monochemotherapy with vincristine is considered to be very effective and less toxic than other therapeutic interventions (Nak et al., 2005).

Nevertheless, during treatment of CTVT, vincristine may cause different side-effects, such as gastrointestinal symptoms (nausea, vomiting, and diarrhea), weight loss and anorexia, depression and paralysis, elevated body temperature, myelosuppression, hair loss, or neurological symptoms, as well as quantitative and qualitative alterations of semen. Even death has been reported (Nak et al., 2005). Regarding the high number of CTVTs to be treated and the household budget restrictions in governmental institutions, it is necessary to look for simple and cheap diagnostic procedures which would enable us to accompany treatment or even predict treatment outcome of CTVT.

Performance status or quality of life scores are important in human medicine (Lorand-Metze et al., 2004), but also of increasing interest in veterinary sciences (Hahn et al., 1994; Yazbek and Fantoni, 2005). Performance scores are applied for pre-treatment evaluations of oncologic patients, since they have shown to be predictive for therapy outcome.

The aim of this prospective study was to investigate whether clinical characteristics at diagnosis and particularly a performance score could indicate an increased risk for adverse events or death during vincristine therapy.

\section{MATERIAL AND METHODS}

Ninety-three dogs with naturally occurring CTVT were prospectively evaluated from 2003 to 2007 at the Center of Zoonosis Control, Taubaté, in the State of São Paulo. The study was approved by the Committee of Ethics in Animal Research at the Universidade Estadual de Campinas (UNICAMP).

A punch biopsy of the tumor was performed under atropine sulfate $(0.1 \mathrm{mg} / \mathrm{kg})$ and anesthesia with xylazine $(3 \mathrm{mg} / \mathrm{kg})$ and ketamine hydrochloride $(15 \mathrm{mg} / \mathrm{kg})$. HE-stained cytological touch preparations were done. In every case, the diagnosis of CTVT was confirmed by microscopic examination of the cytologic slides, according to the morphologic criteria previously published (Santos et al., 2001; Santos et al., 2008). All animals were subjected to clinical examinations. Concomitant diseases, breed, gender, weight, age, status as owned dog, tumor volume (estimated with calipers according to the formula: length $\times$ width $\times$ height $\times \pi / 6$ ), and the season of the year were recorded. The months from June to August, were defined as 'cold and dry period' (mean minimal monthly temperature [ $\pm \mathrm{SD}]: \quad 9.9 \pm 3.8^{\circ} \mathrm{C} ;$ mean maximal monthly temperature: $25.0 \pm 4.5^{\circ} \mathrm{C} ; 3.3 \pm 2.03$ average days of precipitation per month), as opposed to the remaining of the year, which was termed 'hot and rainy' (mean minimal monthly temperature: $15.5 \pm 3.1^{\circ} \mathrm{C}$; mean maximal monthly temperature: $27.4 \pm 2.8^{\circ} \mathrm{C} ; 12.3 \pm 4.7$ average days of precipitation per month).

The performance status was evaluated at diagnosis and at weekly intervals during treatment by a modified Karnofsky Performance Score (Karnofsky and Burchenal, 1949), adapted for dogs (canine Karnofsky score, CKS) (Table 1). The modified Karnofsky score tries to evaluate to what extent the tumor, concomitant diseases, or treatment side effects compromise quality of life and restrict normal activities or even essential for daily life, such as food and water intake. The term 'localized accompanying disease of minor importance' is equivalent to minor pathologic alterations restricted to one organ, which do not provoke systemic alterations, such as fever or lethargy and which do not compromise activities of daily life (e.g.: purulent vaginal secretion, neoplasm with ulcerated surface, cough without fever, etc). 'Localized accompanying disease of major importance' reflects a more severe pathologic alteration of an organ, always accompanied by generalized systemic alterations such as fever or lethargy (e.g.: pneumonia). For comparison, the simplified Karnofsky score (SKS) was determined (Hahn and Richardson, 1995), which is defined as following: 0: uncompromised quality of life, 1: demonstrating clinical signs directly related to the disease without compromised quality of life, 2: compromised quality of life with normal defecation and urination behavior, 3: severely compromised quality of life, and 4: dead. 
Table 1. Human Karnofsky Performance Score and Karnofsky score adapted for dogs

\begin{tabular}{|c|c|c|}
\hline Score & $\begin{array}{l}\text { Karnofsky score in } \\
\text { human medicine }\end{array}$ & Karnofsky score adapted for dogs (CKS) \\
\hline 100 & $\begin{array}{l}\text { Normal, no complaints, no evidence } \\
\text { of disease. }\end{array}$ & $\begin{array}{l}\text { Normal activities of daily living (ADL), no clinical } \\
\text { evident alterations even with the presence of a small } \\
\text { asymptomatic tumor. }\end{array}$ \\
\hline 90 & $\begin{array}{l}\text { Able to carry on normal activity: } \\
\text { minor symptoms of disease. }\end{array}$ & $\begin{array}{l}\text { Normal ADL, one organ with localized accompanaying } \\
\text { disease of minor importance. }\end{array}$ \\
\hline 80 & $\begin{array}{l}\text { Normal activity with effort: some } \\
\text { symptoms of disease. }\end{array}$ & $\begin{array}{l}\text { Normal ADL, two organs with localized accompanying } \\
\text { disease of minor importance. }\end{array}$ \\
\hline 70 & $\begin{array}{l}\text { Cares for self: unable to carry on } \\
\text { normal activity or active work. }\end{array}$ & $\begin{array}{l}\text { At least one organ with accompanying disease of major } \\
\text { importance. Mild letargy over baseline (letargy grade } \\
\text { 1); normal appetite. }\end{array}$ \\
\hline 60 & $\begin{array}{l}\text { Requires occasional assistance but is } \\
\text { able to care for needs. }\end{array}$ & $\begin{array}{l}\text { At least one organ with accompanying disease of major } \\
\text { importance. Moderate lethargy causing some dificulty } \\
\text { with performing ADL (letargy grade 2). Slightly } \\
\text { decreased appetite and normal water intake. }\end{array}$ \\
\hline 50 & $\begin{array}{l}\text { Requires considerable assistance and } \\
\text { frequent medical care. }\end{array}$ & $\begin{array}{l}\text { At least one organ with accompanying disease of major } \\
\text { importance. Letargy grade } 2 \text {. Moderately decreased } \\
\text { appetite, normal water intake. }\end{array}$ \\
\hline 40 & $\begin{array}{l}\text { Disable: requires special care and } \\
\text { assistance. }\end{array}$ & $\begin{array}{l}\text { Severely restricited in ADL. Ambulatory only to the } \\
\text { point of performing ADL (letargy grade } 3 \text { ). Severly } \\
\text { decreased appetite. Spontaneous water intake slightly } \\
\text { reduced, but without clinical signs of dehydration. }\end{array}$ \\
\hline 30 & $\begin{array}{l}\text { Severely disabled: hospitalization, } \\
\text { death not imminent. }\end{array}$ & $\begin{array}{l}\text { Letargy grade } 3 \text {. Animal still stands up spontaneously } \\
\text { and remains standing for a while; restrainment } \\
\text { necessary during examinations or therapy. Severly } \\
\text { decreased appetite and spontaneous water intake, } \\
\text { clinical signs of dehydration. }\end{array}$ \\
\hline 20 & $\begin{array}{l}\text { Very sick, hospitalization necessary: } \\
\text { active treatment necessary. }\end{array}$ & $\begin{array}{l}\text { Disabled, must be force fed and helped to perform } \\
\text { ADL (letargy grade 4). Remaining most of the time in } \\
\text { lateral decubitus and stands up only for defecation or } \\
\text { urination; slight restrainment for examination or } \\
\text { treatment still necessary. }\end{array}$ \\
\hline 10 & $\begin{array}{l}\text { Moribund, fatal } \\
\text { progressing rapidly. }\end{array}$ & $\begin{array}{l}\text { Absent ADL, dog remains constantly in lateral } \\
\text { decubitus, even during defecation or urination; } \\
\text { restrainment no longer necessary for examination or } \\
\text { treatment, moribund. }\end{array}$ \\
\hline 0 & Death. & Death. \\
\hline
\end{tabular}

Non-owned dogs were housed at the facilities of the Center of Zoonosis Control. They were fed a balanced diet and had free tap water. Animals with concomitant purulent inflammatory disease received antibiotic therapy. If necessary, parenteral fluid therapy or nutrition was applied. After therapy of accompanying diseases, the animals were treated with vincristine sulphate $(0.025 \mathrm{mg} / \mathrm{kg})$ (Das and Das, 2000; Nak et al., 2005) administered in the cephalic vein at weekly intervals until the tumor had macroscopically disappeared, which was defined as complete remission.
During chemotherapy, all animals were submitted to a complete clinical examination at weekly intervals. Basic clinical data were recorded, such as weight, CKS and SKS, and the occurrence of adverse events, which were described and graded according to suggestions of the Veterinary Co-operative Oncology Group (VCOG 2004). When necessary, treatment support was given as aforementioned.

In order to measure the reproducibility of the newly developed CKS, two veterinarians (MLV and $\mathrm{KSC}$ ) rated independently 32 randomly selected dogs, which did not enter the main 
study. The inter-observer reproducibility was measured with the help of the kappa statistics Graphpad software/2008. CKS values at the beginning and at the end of therapy were compared with the help of the Wilcoxon test and frequencies with the chi-square or McNemar test. Time-event curves were analyzed with the logrank test and the Cox proportional hazards regression model. For the survival study, the period of observation was from the beginning of chemotherapy to the fourth week after complete remission. Animals were censored, when therapy was abandoned or when they died due to an accident. For the evaluation of the adverse events, the time from the beginning to the end of chemotherapy was recorded.

The first adverse event observed during therapy was defined as "event". Initially, the covariates: gender, breed, weight, status as owned dog, tumor volume, logarithmated tumor volume, the season of the year, SKS, CKS, and the presence of concomitant purulent inflammation or cachexia were tested individually in univariate analyses. Then, those variables with $\mathrm{P}<0.10$ entered a multivariate Cox regression (stepwise backward conditional with $\mathrm{P}=0.05$ for input and $\mathrm{P}=0.10$ for output). The proportionality assumption was always checked. Furthermore, the $\mathrm{R}^{2}$ values of the regressions were calculated (Lorand-Metze et al., 2004; Rybka et al., 2008), which represent the goodness-of-fit of the mathematical model; thus, estimating the approximation of the algorithm to clinical and biological reality. Then, for both multivariate Cox models, 100 new data sets were created, each by bootstrap resampling of the original data with replacement. In an individual new bootstrap sample, a patient may be represented once, multiple times, or not at all. The Cox-regression was applied to every new data set and the independent variables were recorded. This procedure is very useful to test the stability of the initially obtained mathematical model and points out the most important independent variables (Lorand-Metze et al., 2004). Finally, a cluster analysis according to the Ward algorithm (Metze et al., 2000; Oliveira et al., 2001) was applied on the CKS values. Survival differences of the groups were analyzed with the log-rank test. For statistical tests, Winstat 3.1 and SPSS 10.0 software were used.

\section{RESULTS}

In 71 animals, the tumor was located at the vulva or vagina; in 13, at the penis; in one case, at the lower lip; and in another dog, at the lower eyelid. Fifty-two dogs were owned, 83 of mixed breed. Tumor size ranged from $0.7 \mathrm{~cm}^{3}$ to $121.5 \mathrm{~cm}^{3}$ (median $11.45 \mathrm{~cm}^{3}$ ). Eleven animals suffered from seborrheic dermatitis, 19 from alopecia, and five revealed areas of erythema. In 19 animals, a purulent inflammatory process was diagnosed, e.g. ulcerated tumor, purulent anal secretion, otitis etc. Four animals showed slight to moderate weight loss. Three animals revealed skin tumors unrelated to CTVT and two dogs had sequelae from previous fractures. One dog suffered from dehydration. Ten dogs showed mild and seven moderate lethargy. When comparing the frequency of animals with concomitant purulent inflammatory diseases admitted in hot or cold months, there were no significant differences (Table 2).

Table 2. Changes of the modified Karnofksy score in subgroups comparing values at the beginning and at the end of treatment (Wilcoxon test) of dogs

\begin{tabular}{lcccccccccc}
\hline $\begin{array}{c}\text { CKS/ } \\
\text { Concomitant } \\
\text { disease }\end{array}$ & $\begin{array}{c}\text { Cold } \\
\text { and } \\
\text { dry } \\
\text { months } \\
(\mathrm{n}=27)\end{array}$ & $\begin{array}{c}\text { Hot } \\
\text { and } \\
\text { rainy } \\
\text { months } \\
(\mathrm{n}=66)\end{array}$ & $\begin{array}{c}\text { Owned } \\
(\mathrm{n}=53)\end{array}$ & $\begin{array}{c}\text { Non- } \\
\text { owned } \\
(\mathrm{n}=40)\end{array}$ & $\begin{array}{c}\text { Male } \\
(\mathrm{n}=15)\end{array}$ & $\begin{array}{c}\text { Female } \\
(\mathrm{n}= \\
78)\end{array}$ & $\begin{array}{c}\text { Mongrel } \\
(\mathrm{n}=83)\end{array}$ & $\begin{array}{c}\text { Breed } \\
(\mathrm{n}=10)\end{array}$ & $\begin{array}{c}\text { Purulent } \\
\text { inflammation } \\
(\mathrm{n}=20)\end{array}$ & $\begin{array}{c}\text { Without } \\
\text { purulent } \\
\text { inflammation } \\
(\mathrm{n}=73)\end{array}$ \\
\hline $\begin{array}{l}\text { CKS at the } \\
\text { beginning }\end{array}$ & 88.5 & 84.7 & 87.0 & 84.3 & 85.6 & 87.1 & 85.5 & 88.0 & 77.0 & 88.2 \\
$\begin{array}{l}\mathrm{CKS} \text { at } \\
\text { the end }\end{array}$ & 94.8 & 85.8 & 92.6 & 82.8 & 87.3 & 94.3 & 88.8 & 85.0 & 84.0 & 89.6 \\
$\mathrm{P}$ value & 0.01 & 0.05 & 0.0001 & 0.78 & 0.027 & 0.011 & 0.004 & 0.50 & 0.039 & 0.049 \\
\hline
\end{tabular}


In the pilot study, the interobserver reproducibility of the CKS had high concordance (kappa=0.735; weighted kappa=0.835). At admission, 23 dogs with CTVT had a CKS of 100,33 of 90 , and 20 of 80 . Ten animals of 70 , six of 60 , and one dog had 50. The mean CKS value (considering all animals) improved from 85.8 to 88.4 . In nine dogs, a temporary decrease of the CKS values was seen, predominantly in the second or third weeks, but then they returned to pre-treatment levels. When treatment was done during the 'cold and dry period', CKS increased more during treatment than in 'hot and rainy months'. Mongrel dogs or owned dogs showed a significant improvement of the CKS values, whereas this was not the case for nonowned animals or dogs with breed (Table 2).

Complete remission was achieved in 75 dogs with a median of five injections (ranging from 1 to 16$)$. The remaining 18 animals had abandoned therapy and seven expired.

The median observation time for the study on adverse events was four weeks (ranging from 1 to 14 weeks). During chemotherapy, 17 animals presented one to five adverse events which were observed from the second to the $10^{\text {th }}$ week. Four animals presented a temporary weight of loss (grade 2) but regained weight at the end of treatment. Their CKS did not significantly change from the beginning to the end of the therapy. Five animals suffered a progressive permanent weight of loss (grades 2 and 3, two animals each), which was paralleled by a significant decrease of the CKS values (mean: 50; $\mathrm{P}=0.04)$. Ten dogs developed serous nasal secretion, whereas this had not been observed in any dog before treatment $(\mathrm{P}<0.01)$. When each variable was tested for the occurrence of adverse events, the Cox regression revealed neither CKS $(\mathrm{P}=0.19)$ nor SKS $(\mathrm{P}=0.30)$ as favorable factors. When treatment was started in the 'hot and rainy months', there was an increased probability to develop adverse events $(\mathrm{P}=0.029$, Cox Manteltest) (Figure 1). Whereas only one of $27 \mathrm{dogs}$ showed an adverse event during the 'cold and dry months', 23 of 66 animals revealed at least one adverse event in the 'hot and rainy period'. In the univariate Cox regressions, all clinical variables, including the SKS, did not enter the univariate Cox models.

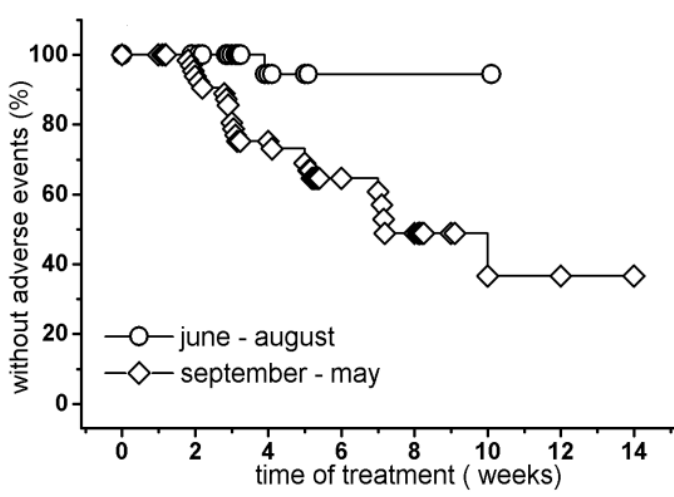

Figure 1. Seasonal variation of the occurrence of adverse events in dogs. June - August corresponding to cold and dry months; September - May corresponding to hot and rainy months ( $\mathrm{P}=0.029$; Cox Mantel-test).

A total of seven animals died during therapy, two of them suffered a sudden unexpected death without presenting adverse events or a previous decline in CKS. Two animals expired due to causes not related to pre-existing diseases or therapy, i.e. a car accident and a snake bite, and were therefore considered censored cases. At the time of death, only the dog expiring due to a snake bite had achieved complete remission. The median observation time of the survival study was nine weeks (ranging from 1 to 21 ). When analyzing survival in univariate analyses, weight $(\mathrm{B}=-0.298 ; \quad \mathrm{P}=0.017), \quad \mathrm{CKS} \quad(\mathrm{B}=-\quad 0.0962$; $\mathrm{P}=0.0015)$, SKS $(\mathrm{B}=1.35 ; \mathrm{P}=0.054)$, but not the status as owned $\operatorname{dog}(\mathrm{P}=0.58)$ were favorable, whereas underweight $(\mathrm{P}=0.57)$ or purulent inflammation at diagnosis $(\mathrm{P}=0.63)$, gender $(\mathrm{P}=0.42)$, breed $(\mathrm{P}=0.88)$, tumor volume $(\mathrm{P}=0.74)$, and "season" $(\mathrm{P}=0.53)$, did not reveal prognostic importance regarding survival. In the multivariate model, only the variables $\mathrm{CKS}(\mathrm{B}=-$ 0.0766; $\mathrm{P}=0.0213)$ and weight $(\mathrm{B}=-0.2386$; $\mathrm{P}=0.0368$ ) showed to be independent prognostic parameters for survival during therapy. In 100 bootstrap resampling models, the variable CKS entered in $93 \%$ and weight in $91 \%$ of the models, whereas the variable SKS appeared only in $2 \%$ of the bootstrap models. When applying a cluster analysis to the CKS values before therapy, two groups were created by the Ward algorithm: dogs with $\mathrm{CKS}=100$ and those with $\mathrm{CKS}<100$. Whereas all 24 animals with a modified Karnofsky score of 100 admission had survived, seven of the 69 animals with CKS from 50 and 
90 to expired (Figure 2). Both groups showed a statistically significant difference in the log-rank test $(\mathrm{P}=0.011)$.

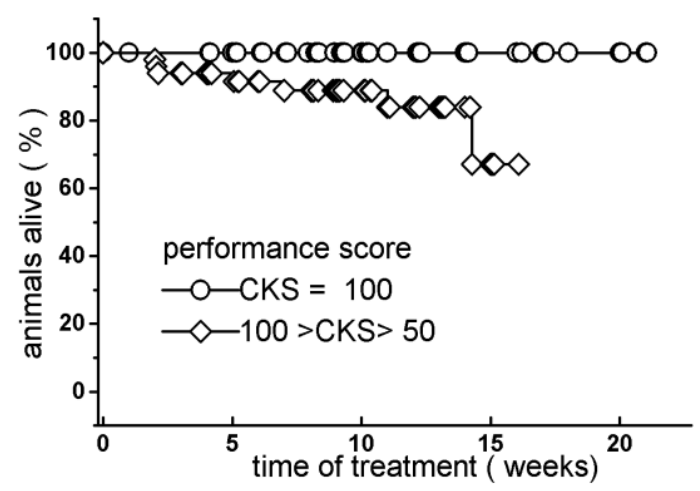

Figure 2. Overall survival during the treatment of canine transmissible venereal tumor according to the modified Karnofsky score at diagnosis. CKS corresponding to modified Karnofsky performance score adapted for $\operatorname{dogs}(\mathrm{P}=0.011$; Cox Mantel-test).

\section{DISCUSSION}

Vincristine is a frequently prescribed agent in veterinary medicine due to its widespread use for feline and canine malignant lymphomas. The gastrointestinal and neurological symptoms, weight loss, and anemia, which were observed in the present study during chemotherapy, are well known complications of this therapy (Nak et al., 2005). Cough and dyspnea may also be caused by therapy, since acute and chronic pulmonary dysfunction has also been reported (Hahn et al., 1994). Increased nasal secretion, however, as observed in this investigation, has to the knowledge of the authors not been reported during vincristine therapy. It could be speculated that this phenomenon might be due to an increased susceptibility to viral infections in the upper respiratory tract during treatment. But a causal relationship cannot be postulated at the moment, since this study did not include a treatment-free control-group due to ethical reasons. An important factor for the occurrence of adverse events in this prospective investigation was the season, which has shown to be important in human (Metze et al., 1994; Lorand-Metze et al., 1998), as well in veterinary medicine (Brown-Brandl et al., 2005; Lacetera et al., 2005). Recently, it had been demonstrated that during hot and rainy months CTVT remission was delayed (Scarpelli et al., 2010), which might be due to a seasonal modulation of the immune system. High environmental temperature may influence the immune system (Brown-Brandl et al., 2005; Lacetera et al., 2005) and increase the frequency of infectious diseases in cattle (Brown-Brandl et al., 2005). Similar mechanisms might be responsible for the higher number of complications during vincristine therapy in hot months as documented in this study. An alternative explanation, however, would be a seasonal increase in diseases not related to chemotherapy. In order to investigate this possibility, the frequency of concomitant inflammatory diseases, underweight, and the CKS values before starting chemotherapy were compared from hot to cold months, but significant differences were not found. It could be hypothesized, that the combination of vincristine chemotherapy together with hot environmental temperatures might be responsible for the increased frequency of adverse events, perhaps due to a modulation of the immune system. But, additional investigations are necessary to clarify this question.

Ogilvie et al. (1989) evaluated the toxic effects of doxorubicine in dogs with a modified Karnofsky performance score and related a significant decrease of the score values provoked by doxorubicin-induced toxicosis. In this study, however, it is difficult to evaluate, whether unfavourable clinical signs or diseases occurring during therapy are related to vincristine or the pre-existing diseases. Therefore, it was used the term 'adverse event', which, in the context of chemotherapy, may or may not be considered related to the medical treatment (VCOG 2004). Hahn et al. (1994) applied the SKS in dogs with malignant lymphomas, but they were not able to demonstrate any prognostic relevance regarding remission or survival time.

In the present study, this simplified score composed of only five categories was compared to a more detailed performance score which was based on the Karnofsky performance score for humans (Karnofsky and Burchenal, 1949), comprising 11 categories. Due to mathematical reasons, a measurement system achieves a higher test power when it is based on a more detailed scoring system, i.e. it will detect more easily even small differences as significant. This 
phenomenon explains the better performance of the CKS.

Death has been reported during vincristine therapy of CTVT ( Nak et al., 2005). Therefore, one aim of this study was to find out whether the CKS could predict animals with a higher risk for death during chemotherapy. Regarding survival, both scores demonstrated to be of prognostic value in univariate Cox regressions, but in the multivariate Cox model, only the CKS entered the final model. The difference was also evident in the bootstrap resampling study. Whereas CKS was present in $93 \%$ of all models, the simplified Karnofsky score was only in $2 \%$. The $\mathrm{R}^{2}$ values also showed a striking difference. The variance of CKS explains $10.8 \%$ of the variance of the Cox regression, compared with only $3.1 \%$ of the simplified score. The main argument for the application of a more simplified score system is its reproducibility, because a diminished number of categories usually increases the concordance rate between different observers. In this case the interobserver reproducibility, as measured by the kappa values, it was excellent for the CKS, thus underlining its clinical utility in veterinary medicine.

In summary, the Karnofsky score adapted for dogs, presented in this investigation, is a simple, cheap, and reproducible clinical instrument, able to estimate the outcome of the patient during treatment of CTVT.

\section{ACKNOWLEDGEMENTS}

This investigation was supported by the administration of the City of Taubate, FAEPEX and FAPESP $\left(\mathrm{n}^{\mathrm{o}}\right.$ 05/52596-8). K.M. is researcher of the Conselho Nacional de Desenvolvimento Científico e Tecnológico (CNPq) (nº 309447/2007-0)

\section{REFERENCES}

ALVES, M.C.G.P.; MATOS, M.R.; REICHMANN, M.L. et al. Dimensionamento da população de cães e gatos do interior do Estado de São Paulo. Rev. Saúde Pública, v.39, p.891897, 2005.
BROWN-BRANDL, T.M.; EIGENBERG, R.A.; HAHN G.L. et al. Analyses of thermoregulatory responses of feeder cattle exposed to simulated heat waves. Int. J. Biometeorol., v.49, p.285-296, 2005.

DAS, U.; DAS, A.K. Review of canine transmissible venereal sarcoma. Vet. Res. Commun., v.24, p.545-556, 2000.

HAHN, K.A.; RICHARDSON, R.C. (Eds). Cancer chemotherapy - a veterinary handbook. Baltimore: Williams \& Wilkins, 1995. p.124125.

HAHN, K.A.; RICHARDSON, E.A.; HAHN, E.A. et al. Diagnostic and prognostic importance of chromosomal aberrations identified in $61 \mathrm{dogs}$ with lymphosarcoma. Vet. Pathol., v.31, p.528540, 1994.

KARNOFSKY, D.A.; BURCHENAL, J.H. The Clinical evaluation of chemotherapeutic agents in cancer. In: MacLEOD, C.M. (Ed). Evaluation of chemotherapeutic agents. New York: Columbia University Press, 1949. 196p.

LACETERA, N.; BERNABUCCI, U.; SCALIA, D. et al. Lymphocyte functions in dairy cows in hot environment. Int. J. Biometeorol., v.50, p.105-110, 2005.

LORAND-METZE， I.; ARANALDE， M.P.; BARBOSA, K.B. et al. Seasonality in the diagnosis of acute lymphocytic leukemia in the southeast region of Brazil. Br. J. Haematol., v.102, suppl., p.38-38, 1998.

LORAND-METZE， I.; PINHEIRO, M.P.; RIBEIRO, E. et al. Factors influencing survival in myelodysplastic syndromes in a Brazilian population: comparison of FAB and WHO classifications. Leuk. Res., v.28, p.587-594, 2004.

METZE, K.; LOBO, A.M.; LORAND-METZE, I. Nucleolus organizer regions (AgNORs) and total tumor mass are independent prognostic parameters for treatment-free period in chronic lymphocytic leukemia. Int. J. Cancer, v.89, p.440-443, 2000.

METZE, K.; MEVES, R.; MOREIRA, P.R.S. Seasonal-variation in rheumatic heart disease. Int. J. Cardiol., v.38, p.101-102, 1994.

MURGIA, C.; PRITCHARD, J.K.; KIM, S.Y. et al. Clonal origin and evolution of a transmissible cancer. Cell, v.126, p.477-487, 2006. 
NAK, D.; NAK, Y.; CANGUL, I.T. et al. A clinico-pathological study on the effect of vincristine on transmissible venereal tumour in dogs. J. Vet. Med. A. Physiol. Pathol. Clin. Med., v.52, p.366-370, 2005.

OGILVIE, G.K.; RICHARDSON, R.C.; CURTIS, C.R. et al. Acute and short-term toxicoses associated with the administration of doxorubicin to dogs with malignant tumors. $J$. Am. Vet. Med. Assoc., v.195, p.1584-1587, 1989.

OLIVEIRA, G.B.; PEREIRA, F.G.; METZE, K. et al. Spontaneous apoptosis in chronic lymphocytic leukemia and its relationship to clinical and cell kinetic parameters. Cytometry, v.46, p.329-335, 2001.

RYBKA, M.O.; CINTRA, M.L.; SOUZA, E.M. et al. Density of dendritic cells around basal cell carcinomas is related to tumor size, anatomical site and stromal characteristics, and might be responsible for the response to topical therapy. Int. J. Dermatol., v.4, p.1240-1244, 2008.

SANTOS, F.G.A.; VASCONCELOS, A.C.; MORO, L. et al. Apoptosis in the canine transmissible venereal tumor: morphological features and biochemical evidence. Arq. Bras. Med. Vet. Zootec., v.53, p.557-562, 2001.
SANTOS, F.G.A.; VASCONCELOS, A.C.; NUNES, J.E.S. et al. Apoptosis in the transplanted canine transmissible venereal tumor during growth and regression phases.

Arq. Bras. Med. Vet. Zootec., v.60, p.607-612, 2008.

SCARPELLI, K.C.; VALLADÃO, M.L.; METZE, K. Predictive factors for the regression of canine transmissible venereal tumor during vincristine therapy. Vet. J., v.183, p.362-362, 2010.

VCOG - Veterinary co-operative oncology group common terminology criteria for adverse events (VCOG-CTCAE) following chemotherapy or biological antineoplastic therapy in $\operatorname{dogs}$ and cats. Vet. Comp. Oncol., v.2, p.195-213, 2004.

YAZBEK, K.V.B.; FANTONI, D.T. Validity of a health-related quality-of-life scale for dogs with signs of pain secondary to cancer. J. Am. Vet. Med. Assoc., v.226, p.1354-1358, 2005. 